\title{
Editorial: Gold Diggers
}

'Gold is dug up in South Africa, and buried again in the United States. What good does this do?' This old question from a Cambridge scholarship paper is brought to mind by The Collected Papers of Bertrand Russell, Volume I: Cambridge Essays, I888-99. The book is the first of 28 volumes that will emerge from the process of disinterment in Europe and reburial in Canada that has created the Russell Archive at McMaster University in Ontario. Russell did not become the great Liberal Prime Minister that his paternal grandmother groomed him to be, but, as the editors say, he 'carried single-handedly the tradition of the Victorian sage into the twentieth century', and that piece of biographical luck confers on these pages a level of interest that few of them could achieve on their own account.

- The British affiliations of five of the twelve members of the Advisory Editorial Board, including the Librarian of Russell's own College, have not saved the Canadian editors of this volume from a number of small errors of English and especially Cambridge usage. Neither Russell's grandmother (whatever her ambitions) nor Russell himself (in spite of the Americanisms in some late letters to The Times) would have spoken of 'Prime Minister Gladstone'. The use of North American terms of academic art (courses, classes) has caused or aggravated some misunderstandings of the Cambridge teaching system. The editors include among their voluminous Annotation and Textual Notes a list of Russell's misspellings, from which they justly exclude 'Sydney Sussex College', since that error occurs in the Annotation and not in the text. Russell is allowed to retain his spellings of the names of Des Cartes and Leibnitz.

The forty-nine papers include the youthful 'Greek Exercises' and 'A Locked Diary', a number of undergraduate and graduate essays, and six papers written for delivery to the Apostles. One of these is entitled: 'Lövborg or Hedda', but 'The subject of my paper has no connection with its title, and it would be a waste of time to explain how I came to think it had. What I wish to discuss is whether, from the point of view of the Society alone, it would be a good or a bad thing if women could be elected.' He tells Alys that when a member noticed 'that my end contradicted my beginning' he showed logical resource: 'I invented a subtlety that reconciled them.' In a graduate essay he commends the Indian custom of Suttee: 'Why waste the means of sustenance on one who can serve no longer for the preservation of the species?' Henry Sidgwick's pencilled comment demurs at this youthful utilitarianism.

Fortunately there is no space to quote either of Russell's sonnets. They are not gold, and they do not glitter. 